\title{
Borsa İstanbul Sürdürülebilirlik Endeksi İşletmelerinin Sera Gazı Beyanlarına Yönelik Güvence Denetimleri: ISAE 3410 Güvence Denetim Standardına İliş̧kin Bir Araştırma
}

\section{Arş. Gör. Dr. Meltem Ece Çokmutlu* Arş. Gör. Şahay Ok ${ }^{2}$}

Geliș tarihi: 01.10.2019

Kabul tarihi: 21.10.2019

\section{Atıf bilgisi:}

IBAD Sosyal Bilimler Dergisi

Sayı: 5

Sayfa: $164-174$

Yil: 2019

Dönem: Güz

This article was checked by Turnitin. Similarity Index $21 \%$

${ }^{1}$ Karabük Üniversitesi İşletme Fakültesi, Türkiye, meltemece@karabuk.edu.tr ORCID No:0000-0002-5260-3925.

${ }^{2}$ Karabük Üniversitesi,İ̧letme Fakültesi, Türkiye, sahayok@karabuk.edu.tr ORCID No: 0000-0003-1420-148X .

* Sorumlu yazar
ÖZ

Kurumsal raporlarda (finansal ve finansal olmayan raporlar) sunulan bir bilginin doğruluğuna bağımsız bir kurulușça güvence verilmesi, bu bilginin karar almada kullanılabilirliğini ve güvenini arttıracaktır. Sunulan finansal bilgiler için uluslararası düzeyde kabul gören standartlaşmış bağımsız denetim hizmetleri mevcuttur. Son yıllarda finansal olmayan bilgiler için de güvence hizmeti sağlayabilecek standartlar hazırlanmaya bașlanmıștır. Bu standartların en bilinenleri Uluslararası Bağımsız Denetim ve Güvence Denetimi Standartları Kurulu (IAASB) tarafindan hazırlanan standartlardır. Kurul tarafindan hazırlanan spesifik standartlardan biri de ISAE 3410 "Sera Gazı Beyanlarına İlişkin Güvence Denetim Standardı"dır. Bu çalışmada güvence denetimi standartları kapsamında bulunan ISAE 3410 standardı açıklanmış ve Borsa İstanbul Sürdürülebilirlik endeksinde yer alan işletmelerin sundukları finansal olmayan raporlarda bu standarda ilişkin açıklamaları ölçülmüștür. Ölçüm yapılırken elde edilen finansal olmayan raporlardan (sürdürülebilirlik raporları ve entegre raporlar) içerik analizi yöntemi kullanılarak ilgili bilgiler toplanmış ve frekans dağılımı ile çözümlenmiştir. Araştırmanın sonucu genel olarak değerlendirildiğinde; işletmelerin sera gazı beyanlarına ilişkin açıklamalarının yüksek olduğu ve işletmelerin ISAE 3410 standardına ilişkin farkındalıklarının olduğu görülmektedir.

Anahtar Kelimeler: Güvence Denetimi, Güvence Sözleșmeleri, ISAE 3410, Sürdürülebilirlik Endeksi 


\title{
Assurance Audit of Borsa İstanbul Sustainability Index Enterprises for Greenhouse Gas Declaration: A Research on ISAE 3410 Assurance Audit Standard
}

\author{
Arş. Gör. Dr. Meltem Ece Çokmutlu ${ }^{1 *}$ \\ Arş. Gör. Şahay Ok ${ }^{2}$
}

First received: 01.10 .2019

Accepted: 21.10.2019

\section{Citation:}

IBAD Journal of Social Sciences

Issue: $5 \quad$ Pages: 164-174

Year: 2019 Session: Fall

\begin{abstract}
The review and assurance of the accuracy of the information presented in corporate reports (financial and non-financial reports) by an independent organization will increase the usability and confidence of this information in decision-making. Internationally accepted standardized independent auditing services are available for the financial information provided. In recent years, standards have been started to provide assurance services for non-financial information. The best known of these standards are those prepared by the International Standards on Auditing and Assurance Standards (IAASB). One of the specific standards prepared by the Board is ISAE 3410 Assurance Audit Standard for Greenhouse Gas Declarations". In this study, the assurance standard (ISAE 3410) regarding the greenhouse gas declarations within the scope of assurance audit standards is explained and the explanations of ISAE 3410 greenhouse gas assurance standard in the non-financial (n) Borsa Istanbul Sustainability Index were measured. During the measurement relevant information was collected from non-financial reports (sustainability reports and integrated reports) using content analysis method and these data analyzed by frequency distribution. When the result of the research is evaluated in general; It is observed that the companies

have a high level of disclosure about greenhouse gas declarations and that they have awareness about ISAE 3410 greenhouse gas assurance standard.
\end{abstract}

This article was checked by Turnitin. Similarity Index $21 \%$

${ }^{1}$ Karabük Universitiy, Turkey, meltemece@karabuk.edu.tr ORCID ID 0000-0002-5260-3925

${ }^{2}$ Karabük Universitiy, Turkey, sahayok@karabuk.edu.tr, ORCID ID 0000-0003-1420-148X.

* Corresponding Author
Keywords: Assurance Audit, Assurance Engagements, ISAE 3410, Sustainability Index 


\section{GİRIŞ}

Son yıllarda denetim firmaları tarafından sunulan hizmetlerin kapsamında değişiklikler olduğu görülmektedir. $\mathrm{Bu}$ değişikliklerin temel nedenlerini; sürdürülebilirliğe ilişkin farkındalığın artması, paydaşlarca talep edilen bilgilerdeki değişiklik ve çeşitlilik, teknolojik gelişmeler, uluslararasılaşma vb. şekilde sıralamak mümkündür. (Kardeş Selimoğlu ve Özsözgün Çalışkan, 2016, s. 3, Altıntaş, 2010, s.172).

Günümüzde denetim firmaları tarafından bağımsız denetimin yanı sıra, işletmelerin kontrolleri, bilgi sistemleri, tahmini finansal bilgileri gibi çeşitli hususlarda da güvence hizmetleri verilmektedir. İşletmelerin karşılaştıkları yeni risk türleri ve sundukları bilginin kapsamının artışı güvenceye olan talebi de artırmaktadır. Örneğin paydaşlara sunulan bilginin yanlışlığı yasa dışıdır ve mahkeme süreci sonucunda itibar kaybı gibi daha büyük sorunları da beraberinde getirmektedir. İşletmeler sosyal denetimin bir gereği olarak da finansal olmayan bilgilere dair güvence hizmetlerini talep etmeye başlamışlardır (Çıtak, 2015, s. 20-21). Finansal olmayan bilgilere ilişkin alınan güvence hizmetlerine örnek olarak;

$>$ İnternet sitesi kontrollerine ilişkin güvence hizmeti

$>$ Mali sektör dışındaki işletmeler için bilgi sistemleri güvenilirliğine ilişkin güvence hizmeti

> Kurumsal sosyal sorumluluk/sürdürülebilirlik/çevre raporlarına ilişkin güvence hizmeti

$>$ Tahmini finansal tablolara ilişkin güvence hizmeti

> Üzerinde mutabık kalınan işlem sözleşmeleri (AUP), Sermaye Piyasası Mevzuatı dışındaki işletmeler için iç kontrol sisteminin etkinliğine ilişkin güvence hizmeti

$>$ Sera gazı/karbon emisyonu beyanlarına ilişkin güvence hizmeti verilebilir (Altıntaş, 2010, s. 120).

Dünya üzerinde yerel ve küresel düzeyde güvence denetim standartları belirlenmekte ve güvence hizmetleri sunulmaktadır. Örneğin Amerika, Avrupa ve Japonya'da finansal olmayan raporlara ilişkin olarak alınan güvence denetimlerinin fazla olduğu görülmektedir (Çıtak, 2015; Altıntaş, 2011). Uluslararası düzeyde kabul gören standart düzenleyici kuruluşlarda biri de IAASB'dir. Kuruluş başlangıçta daha ziyade finansal tabloların denetimine odaklansa da günümüzde toplum çıkarlarıyla aynı doğrultuda olan denetim ve güvence hizmetlerine ilişkin standartlar oluşturmaktadır. Kuruluş tarafından yayımlanan standartları şu şekilde belirtmek mümkündür:

- Tarihi finansal bilgilerin (finansal tablo ve dipnotlarının) denetlenmesi ile ilgili "Uluslararas1 Denetim Standartları" (IASs)

- Tarihi finansal bilgilerin gözden geçirilmesi ve yorumlanması ile ilgili "Gözden Geçirme Üzerine Standartlar" (ISREs)

- Tarihi finansal bilgilerden ziyade herhangi bir konudaki bilgilendirmeyi güvence altına alacak hizmetler ile ilgili "Güvence Altına Alma Sözleşmeleri Üzerine Standartlar" (ISAEs)

- Profesyonel meslek mensupları tarafından sunulan diğer ilgili hizmet sözleşmelerine uyulacak esasları içeren "Diğer Hizmetler Üzerine Uluslararası Standartlar" (ISRSs)(Çıtak, 2015, s. 2021).

Bu standartlara ek olarak IAASB, sürdürülebilirlik ve iç kontrol hakkında raporlama gibi konuya özel denetim standartları da yayımlamaktadır (Altıntaş, 2010). ISAE 3410 standardı da ifade edilen bu standartlardandir.

Bu çalışmanın temel amacı ülkemizde güvence denetim standartlarından olan ISAE 3410 standardına ilişkin farkındalık düzeyini belirlemektir. Bu amaçla ilk olarak bu güvence denetim standardına ilişkin açıklamalar yapılmış, sonrasında Borsa İstanbul sürdürülebilirlik endeksinde yer alan işletmeler tarafindan sunulan finansal olmayan raporlar (sürdürülebilirlik raporları ve entegre raporlar) ISAE 3410 denetim standardı açısından incelenmiştir. 


\section{SERA GAZI BEYANLARINA İLISSKIN GÜVENCE STANDARTLARI ve ISAE 3410 SERA GAZI GÜVENCE DENETIM STANDARDI}

Sera gazı; yeryüzü, atmosfer ve bulutlar tarafından kızılötesi spektrum 1şıma aralığında belirli dalga boylarında soğurulan ve salınan, atmosferin hem doğal hem de antropojenik gaz bileşeni olarak tanımlanmaktadır (Sezer Özçelik, 2016, s. 3). Karbondioksit (CO2), Metan (CH4), Diazotmonoksit (N2O) sera gazı türlerine örnek olarak verilebilir (Kardeş Selimoğlu, Özsözgün Çalışkan, 2016, s. 6). Tanım olarak sera gazı emisyonu ise; belirli bir sürede atmosfere salınan sera gazlarından birinin toplam kütlesi olarak ifade edilmektedir (Sezer Özçelik, 2016, s. 3).

Kuruluşlar için sera gazı emisyonları ile mücadele sürdürülebilir kalkınma kavramının artan önemi, Kyoto Protokolü, Rio Denklerasyonu, Birleşmiş Milletler Küresel İlkeler Çerçeve Sözleşmesi vb. birçok düzenlemenin direktifleri nedeniyle zorunluluk haline gelmiştir. Artan sera gazı salınımlarındaki artış ve bunun küresel ısınmada yarattığı olumsuz sonuçlar nedeniyle sürdürülebilir kalkınmanın lokomotifi olan işletmelerin bu konuya verdikleri önem de artmaktadır. Bu sayede işletmelerin finansal olmayan raporlarında (çevre raporları, sürdürülebilirlik raporları, entegre raporlar) sera gazı/karbon salınımına ilişkin açıklamalarda da artış görülmektedir (Kardeş Selimoğlu ve Özsözgün Çalışkan, 2016; Yükçü ve Kaplanoğlu, 2016, s. 72). İşletmelerin sera gazı salınımlarına ilişkin yapılan açıklamalarının doğruluğunun sağlanması paylaşılan bilgiye olan güveni arttıracağı; karbon ayak izinin yanlış hesaplanma riskini azaltacağı; işletme karşıtı çevresel iddialara kanıt olacağı karar alıcılara objektif ve tutarlı bilgi sağlayacağı için önemlidir ve bu sebeple sera gazı açıklamaları işletmeler tarafından son yıllarda gerçekleştirilen faaliyetlerdendir (Kardeş Selimoğlu ve Özsözgün Çalışkan, 2018, s. 1-18).

İşletmeler bu denetim hizmetini alırken güvence uygulayıcılardan (bağımsız denetçi veya diğer güvence uygulayıcılar) yararlanmaktadır. Güvence uygulayıcıları ise ISAE 3410, ISO 14064 serileri, ISAE 3000 standartlarını temel alarak doğrulama işlemi gerçekleştirmektedirler (Altuğ ve Özkan, 2015; Kardeş Selimoğlu ve Özsözgün Çalışkan, 2018).

ISO 14064 Standart Serileri: Uluslararası Standart Örgütü (ISO); Sera gazı emisyonlarının izlenmesi, raporlanması ve doğrulanması" konularına ilişkin güvence uygulayıcılarına hitaben birtakım standartlar geliştirmiştir. Bu standartlar;

- ISO 14064-1 Sera Gazları; Sera Gazı Emisyonlarının ve Uzaklaştırmalarının Kuruluş Seviyesinde Hesaplanmasına ve Rapor Edilmesine Dair Kılavuz ve Özellikler,

- ISO 14064-2 Sera Gazları; Sera Gazı Emisyon Azaltmalarının veya Uzaklaştırma İyileştirmelerinin Proje Seviyesinde Hesaplanmasına, İzlenmesine ve Rapor Edilmesine Dair Kılavuz ve Özellikler,

- ISO 14064-3 Sera Gazları; Sera Gazı Beyanlarının Doğrulanmasına ve Onaylanmasına Dair Kilavuz ve Özellikler standartlarıdır (Altuğ ve Özkan, 2015).

ISAE 3410 - Sera Gazı Beyanlarına Yönelik Güvence Standardı (Assurance Standards on Greenhouse Gas Statements); işletmelerin sera gazı beyanlarına yönelik sundukları raporlarla ilgili güvence denetimlerini konu almaktadır (Atabay, 2018, s. 57)

Ülkemizde sera gazı emisyonlarına ilişkin yasal gereklilik, 17 Mayıs 2014 tarihli, 29003 sayılı, "Sera Gazı Emisyonlarının Takibi Hakkında Yönetmelik" ile hayata geçirilmiştir. Yönetmelik ile belirtilmiş olan faaliyetlere ilişkin sera gazı emisyonlarının izlenmesi, raporlanması ve doğrulanması işlemleri düzenlenmektedir. Tanım olarak doğrulama işlemi; bir plana göre izlenen emisyon miktarına ait hem izleme planı hem de izleme raporlarının bir doğrulayıcı kuruluş (denetçi) tarafından doğruluğunun denetlenmesidir. Doğrulayıcı kuruluşlar ise TÜRKAK (Türkiye Akreditasyon Kurumu) tarafindan akredite edilen ve bakanlık (Çevre ve Şehircilik Bakanlığı) adına hareket eden kuruluşlardır (Kardeş Selimoğlu ve Özssözgün Çalışkan, 2016b, s. 19). 


\section{LITERATÜR İNCELEMESI}

ISAE 3410 standardı yeni bir standart olduğu için literatürde konuya ilişkin fazla çalışma bulunmamaktadır, daha ziyade güvence hizmetleri, güvence denetimleri ve denetim standartlarına ilişkin çalışmalara rastlanmaktadır.

O'dwyer ve Owen (2005) çalışmasında, 2002 yılında ACCA, İngiltere ve Avrupa sürdürülebilirlik raporları ödül listesinde yer alan işletmelerin çevresel, sosyal ve sürdürülebilirlik raporlarında yer alan güvence beyanları incelenmektedir. Analiz sonucunda güvence uygulamalarında bağımsız olmanın ve titiz bir tutum sergilemenin olumlu gelişmeler olduğu belirlenmektedir. Güvence uygulamalarındaki paydaş katılımının eksikliği, güvence sürecinde yönetimin kontrolü elinde tutması araştırma sonucunda ulaşılan olumsuz noktalar olmaktadır.

Simnett ve Nugent (2007)'deki çalışmasında Avusturalya'da, ASX'de 2005 yılında yer alan işletmelerin karbon emisyon açıklamaları ve güvence beyanlarının seviyeleri yıllık raporları ve diğer raporları üzerinden araştırılmış olup, söz konusu işletmeler arasında karbon emisyonuna ilişkin yıllık raporlarında açıklamalarda bulunan işletmelerin oranının \%10'dan az olduğu belirlenmiştir.

Simnett vd. (2007) çalışmasında 31 ülkeden 2141 işletmenin finansal olmayan raporlarını güvence beyanlarının varlı̆̆ 1 ve denetçi seçimleri üzerinden 2002-2004 dönemleri için incelemiştir. Bu işletmelerin \%31'inin raporlarında güvence yer almakta, $\% 42$ 'sinde profesyonel denetçiler tarafindan güvence verilmektedir. İşletmeler tarafından gönüllü olarak gerçekleştirilen finansal olmayan raporlarda güvence beyanında bulunma talebinin zaman içinde arttığ 1 belirtilmektedir.

Bir başka araştırma Mock ve arkadaşları tarafından 2007 yılında yapılmıştır. Çalışmada dünya çapında 130 işletmenin 2002-2004 yılları arasındaki güvenceye sahip sürdürülebilirlik raporları incelenmiştir. İşletmelerin ülke ve sektör düzeyinde nasıl bir güvence beyanına sahip olduğu, güvencenin seviyesi, sağlanan güvencenin seviyesini etkileyen faktörler araştırılmıştır. Güvence sağlayan 4 büyük denetim firması ve bu firmaların dışında kalan güvence sağlayıcılar arasındaki ilişki de araştırılmaktadır. Araştırmanın sonuçlarında; güvenceye sahip sürdürülebilirlik raporlarının \%50'den fazlasının Avrupa Birliği'nde olduğu ve \%60'dan fazla rapordaki güvencenin 4 büyük denetim firması dışındaki güvence sağlayıcılardan alındığı ortaya konmaktadır. Sektörler arasında sürdürülebilirlik raporlarında en fazla güvence bulunan 3 sektör ise sirasıyla elektrik ve yardımcı hizmetler $(\% 21,54)$, madencilik ve petrol $(\% 15,38)$ ve üretim $(\% 11,54)$ sektörüdür.

Manetti ve Becatti (2009)'nin GRI Database $2007^{`}$ de yer alan GRI-G3'e göre raporlama yapan sürdürülebilirlik raporlarında güvence beyanı bulunan 34 işletmeyi analiz ettikleri çalışmalarında 14 güvence beyanının ISAE 3000, dokuz beyanın AA10000AS, dokuz beyanın hem ISAE 3000 hem de AA1000AS yedi beyanın ise diğer standartları ifade ettiği belirtilmektedir. Araştırmada güvence sözleşmelerinin seviyeleri, disiplinler arası olup olmadığı, doğrulama türleri, denetim riskinin değerlendirilip değerlendirilmediği, sonuç raporunun olup olmadığı da içerik analizi yöntemi ile incelenmiştir.

Perego ve Kolk (2010) yaptıkları çalışmada çevresel ve sosyal raporlamada güvence talebini ülke düzeyindeki karakteristikler üzerinden analiz etmiştir. Fortune Global 250 işletmelerinin 1999, 2002 ve 2005 yıllarında yayınladıkları raporlarından elde edilen analiz sonuçlarına göre; veri setindeki işletmelerin \%35'inden fazlasının güvence beyanı bulunmaktadır. Avrupa ve Japonya'daki işletmeler daha fazla güvence beyanına sahip ülkelerdir. Bu ülkelerdeki çevreye karşı hassasiyeti olması gereken üretim işletmelerinin yanı sıra bankacılık ve sigortacılık sektöründeki işletmeler de güvenilir raporlar üretmektedir. Güvence sağlayıcı kuruluşların sayısındaki artış, bu alanda faaliyet gösteren ve güvence sunan muhasebe firmaların sayısında hafif bir düşüşe neden olmuştur. ABD'de ise Avrupa ve Japonya ile karşılaştırıldığında dış güvence düzeyinin düşük olduğu görülmektedir.

Barton (2005), Fan ve Wong (2005), Francis vd (2007), Choi ve Wong (2007) ve Choi vd. (2008) tarafından yapılan çalışmalarda da sürdürülebilirlik raporlarında güvence beyanının kullanımının gönüllü güvence hizmetlerinin daha iyi anlaşılmasını sağlayacağı belirtilmektedir (Kolk ve Perego, 2010, s. 183). 
Perego ve Kolk 2012 yılındaki çalışmalarında Fortune Global 250'de yer alan çok uluslu işletmelerin sürdürülebilirlik güvence uygulamaları 1999-2008 yılları itibariyle 10 yıllık süreçte incelemişlerdir. Denetim uygulamaları, güvence standartlarındaki çeşitlilik, güvence sağlayıcıların türleri, sürdürülebilirlik güvence beyanlarının kalitesi çalışmanın araştırma sorularını oluşturmaktadır. Araştırmanın sonucunda Japonya ve Fransa'da yasal zorunluluklar nedeniyle sosyal ve çevresel raporlamada güvence sunma oranının yüksek olduğu görülmektedir.

Mock vd. (2013) tarafından yapılan çalışma, Mock vd. tarafından 2007 yılında yapıllmış olan çalışma ile karşılaştırma temelindedir. 2007 yılında yapılan çalışmanın analiz sonuçları, 2013 yılı çalışmasının sonuçları ile karşılaştırılmıştır. Bu iki araştırmanın sonuçlarında ülkelerin ve sektörlerin güvence beyanına sahiplik düzeyleri, verilen güvence seviyeleri, güvence seviyelerini etkileyen faktörler tespit edilmiştir. Veri setine ilişkin kapsamlı tanımlayıcı istatistiklere de araştırmada yer verildiği görülmektedir.

Gürtürk ve Hahn tarafindan 2016 yılında yapılan çalışmada, 2013 yılında FTSE 100'de yer alan ve German DAX ve MDAX 'da yer alan 80 işletmenin sürdürülebilirlik raporlarındaki güvence beyanları incelenmiştir. Mevcut sürdürülebilirlik uygulamalarına ilişkin kapsamlı bir karşılaştırma yapabilmek adına Londra ve Frankurt borsalarında piyasa değeri en yüksek işletmeler seçilmiştir. Bu 180 işletmenin 109'unun bağımsız bir şekilde hazırlanmış sürdürülebilirlik raporunun veya entegre raporunun olduğu, bunların ise 61'inin dışsal güvence beyanlarına yer veren işletme olduğu görülmektedir. Raporlar Perego ve Kolk (2012) tarafindan önerilen kodlama cetveli kullanılarak 21 gösterge üzerinden içerik, benzerlik, farklılık, şeffaflık, güvence beyanı gibi kriterler açısından incelenmiştir. İçerik analizi yöntemi kullanılarak işletmeler göstergeler üzerinden puanlanmış ve anlamlı farklılıklar bulunmuştur.

Ülkemizde yapılan çalışmalar incelendiğinde; Altıntaş (2010) tarafından hazırlanan doktora tezinde SPK denetim yetkisi almış denetim firmalarında çalışan meslek mensuplarının güvence hizmetlerine ilişkin görüşleri kapsamlı anket çalışması ile değerlendirilmiştir. Araştırmanın sonucunda ülkemizde güvence hizmetlerinin yaygın olmadığı görülmektedir. Gerekli mesleki bilgilendirmenin yapılması ve hukuki düzenlemelerin gelişmesiyle güvence hizmetlerinin yaygınlaşacağı öngörülmektedir.

Dinç ve Atabay (2016) tarafindan yapılan çalışmada güvence denetimi, güvence denetim standartları teorik olarak genel hatları itibariyle incelenmiştir.

Kardeş Selimoğlu ve Özsözgün Çalışkan (2016a, 2016b) çalışmasında ISAE 3410 denetim standardını sürdürülebilirlik bağlamında ele almışlar, denetim öncesinde işletmelerin muhasebe kayıtlarının karbon piyasalarına uygunluğu adına önerilerde bulunmuşlar, ISAE 3410 standardını kavramsal açıdan derinlemesine incelemişlerdir.

\section{ARASTTIRMANIN METODOLOJISİ}

\subsection{Araştırmanın Amacı ve Kapsamı}

$\mathrm{Bu}$ araştırmada Borsa İstanbul sürdürülebilirlik endeksinde yer alan ve kurumsal sürdürülebilirlik performanslarının yüksek olduğu düşünülen işletmelerin, sürdürülebilirlik veya entegre raporlarında sundukları sera gazı beyanlarına ilişkin açıklamalar incelenmiştir. Sürdürülebilirlik endeksi 2014 yılında hesaplanmaya başlayan oldukça yeni bir endekstir. Örneklem seçiminde bu endeksin tercih edilme sebebi, endekste yer alan işletmelerin sürdürülebilirlik konusundaki duyarlılığının yüksek olduğunun öngörülmesidir.

Güvence denetimi ve ISAE 3410 standardı ülkemiz literatürü için daha çok yeni ve geliştirilmeye açık çalışma alanlarıdır. Bu nedenle çalışmada temel amaç, bu alanların tanınırlığına katkıda bulunmaktır.

Sürdürülebilirlik Endeksinde 2014 yılında 15 işletme, 2015 y1lında 29 işletme 2016 yılında 42 işletme 2017 yılında 44 işletme ve 2018 yllında 50 işletme yer almıştır. Bu 180 işletmenin endekse dahil olduğu yıllar itibariyle sürdürülebilirlik veya entegre raporlarına web sayfaları aracılığıyla ulaşılmaya çalışılmıştır. Bağımsız ve/veya GRI standartlarında hazırlanmayan raporlar olması mevcut yıla ilişkin 
olarak sunulmamış raporlar olması nedeniyle analiz 100 finansal olmayan rapor üzerinden gerçekleştirilmiştir.

\subsection{Araștırmanın Soruları}

Araştırma soruları Simnett ve Nugent 2007; Mock vd. 2007; Manetti ve Becatti, 2009; Perego ve Kolk 2012; Mock vd. 2013; Gürtürk ve Hann 2016 çalışmaları incelenerek, ilgili akademisyenleri görüşleri alınarak belirlenmiştir. Araştırmada finansal olmayan raporlar içerik analizi yöntemi ile incelenerek aşağıda ifade edilen temel araştırma sorularına cevaplar aranmaktadır:

- Finansal olmayan raporlarda sera gazı emisyonlarına ilişkin açıklamalar mevcut mudur?

- Sera gazı beyanlarına ilişkin açıklamalar için güvence denetimi alınmış mıdır?

- Sera gazı emisyonlarına ilişkin alınan güvence seviyeleri nasıldır? (Makul, sınırlı)

- Güvence uygulayıcıların sera gazı güvence raporları oluştururken tercih ettikleri standartlar nelerdir? (ISAE3000, ISAE 3410, ISO 14064).

\subsection{Verilerin Elde Edilmesi ve Yöntem}

Araştırmada işletmelerin web sayfalarından elde edilen finansal olmayan raporlan içerik analizine tabi tutulmuş ve veriler toplanmıştır. İçerik analizi; araştırılmak istenen bir metin içerisindeki belirli kelimelerin, kavramların veya nesnelerin var olup olmadığını tespit etmek için kullanılan bir yöntemdir. Temel nitel analiz yöntemi olan içerik analizi sayesinde istenilen kelimeler, kavramlar bir metin, kitap, bölüm, makale vb. eser içinde araştırılır ve bir çıkarımda bulunulur. İstenilirse bu veriler sayısal bir veri haline de dönüştürülebilir. İçerik analizi yöntemi son zamanlarda sürdürülebilirlik raporlarının incelenmesinde sıklıkla kullanılan bir araç olmuştur. Raporlardaki nitel bilgi düzeyinin fazla olması ve karşılaştırmaya imkân vermemesi nedeniyle bu yöntem kullanılarak metin hakkında daha rahat veri elde edilmektedir. İçerik analizinde araştırılan kavram kelime düzeyinde, cümle düzeyinde, sayfa düzeyinde incelenebilir (Aras, Tezcan ve Kutlu Furtuna, 2016, s. 10). Araştırmada içerik analizi ile elde edilen veriler frekans analizi ile çözümlenmiştir.

\subsection{Araştırmanın Bulguları}

100 adet finansal olmayan rapor içerik analizi ile araştırma soruları açısından incelenmiştir. 100 adet finansal raporun 6'sı entegre rapor şeklinde 94'ü ise sürdürülebilirlik raporu şeklindedir. İşletmelerin sürdürülebilirlik raporlarında GRI raporlama ilkelerinde temel düzeyde açıklama yapmayı (\%76) tercih ettikleri görülmektedir. Araştırma sorularına ilişkin bulgulara Tablo 1, Tablo 2 ve Tablo 3 'te yer verilmiştir.

Tablo 1: Sera Gazı Beyanlarına ve Denetimlerine İlişkin Sektörel Açıdan Frekans Dağılımı

\begin{tabular}{|c|c|c|c|c|c|c|}
\hline Sektörler & $\begin{array}{l}\text { İncelenen } \\
\text { Rapor } \\
\text { Sayısı }\end{array}$ & $\begin{array}{l}\text { İncelenen } \\
\text { Rapor } \\
\text { Yüzdesi } \\
(\%)\end{array}$ & $\begin{array}{l}\text { Sera } \quad \text { Gazı } \\
\text { Açıklamasına } \\
\text { Sahip Rapor } \\
\text { Sayısı }\end{array}$ & $\begin{array}{l}\text { Sera Gazı } \\
\text { Açıklamasına } \\
\text { Sahip Rapor } \\
\text { Yüzdesi }(\%)\end{array}$ & $\begin{array}{l}\text { Sera Gazı } \\
\text { Güvence } \\
\text { Denetimine Sahip } \\
\text { Rapor Sayısı }\end{array}$ & $\begin{array}{l}\text { Sera Gazı } \\
\text { Güvence } \\
\text { Denetimine } \\
\text { Sahip } \\
\text { Rapor } \\
\text { Yüzdesi (\%) }\end{array}$ \\
\hline İmalat Sanayi & 48 & 48,0 & 35 & 43,75 & 26 & 46,43 \\
\hline Elektrik Gaz ve Su & 8 & 8,0 & 7 & 8,75 & 4 & 7,14 \\
\hline Mali Kuruluşlar & 27 & 27,0 & 24 & 30 & 17 & 30,36 \\
\hline Teknoloji & 2 & 2,0 & 2 & 2,5 & 1 & 1,79 \\
\hline $\begin{array}{l}\text { Toptan ve } \\
\text { Perakende Ticaret, } \\
\text { Otel ve Lokantalar }\end{array}$ & 7 & 7,0 & 6 & 7,5 & 5 & 8,93 \\
\hline $\begin{array}{l}\text { Ulaştırma, } \\
\text { Haberleşme } \\
\text { Depolama }\end{array}$ & 8 & 4,0 & 6 & 7,5 & 3 & 5,36 \\
\hline Toplam & 100 & 100,0 & 80 & 100 & 56 & 100 \\
\hline
\end{tabular}

Araştırma soruları 1 ve 2 için SPSS'te yapılan frekans dağılım sonuçları Tablo 1'de verilmiştir. Tablo incelendiğinde; analize dahil edilen 100 finansal olmayan raporun en fazla sunulduğu sektör imalat sanayi (\%48) olmuştur. Sonrasında \%27 ile mali kuruluşlar ve $\% 8$ ile elektrik gaz ve su sektörleri gelmiştir. İncelenen 100 raporun 80'inde sera gazına ilişkin açıklamalar bulunmaktadır. 20'sinde ise 
herhangi bir açıklamaya rastlanmamıştır. En fazla açıklama beyanına sahip olan sektör imalat sanayi olmuştur $(\% 43,75)$. İmalat sanayi sektörünü sırasıyla mali kuruluşlar (\%30) ve elektrik gaz ve su sektörleri $(8,75)$ izlemiştir. Araştırmada sera gazı beyanlarına ilişkin güvence denetimin olduğu rapor sayısı ise 56 olmuştur. 44 raporda sera gazı beyanlarına ilişkin güvence denetimlerine rastlanmamıştır. İmalat sanayi sektörü $\% 46,43$ oranıyla en fazla sera gazı güvence denetimine sahip sektör olmuştur. İmalat sanayi sektörünü sırasıyla mali kuruluşlar $(\% 30,36)$ ve toptan ve perakende ticaret $(\% 8,93)$ sektörleri izlemiştir.

Tablo 2: Finansal Olmayan Raporlardaki Sera Gazı Güvence Seviyeleri Frekans Dağılımı $\begin{array}{lll}\text { Güvence Seviyeleri } & \text { Sayı }\end{array}$

\begin{tabular}{lll}
\hline Sinırlı Güvenceye Sahip Rapor & 42 & 42,0 \\
\hline Makul Güvenceye Sahip Rapor & 5 & 5,0 \\
\hline Açıklama Belirtmeyen/Denetim Yapılmayan Rapor & 53 & 53,0 \\
\hline Toplam & $\mathbf{1 0 0}$ & $\mathbf{1 0 0 , 0}$ \\
\hline
\end{tabular}

Tablo 2'de sera gazı beyanlarına güvence seviyelerine ilişkin araştırma sorusunun bulgularına değinilmiştir. İncelenen 100 finansal olmayan raporda \%42 oranında sınırlı güvence alınmış, \%5 oranında makul güvence alınmış, $\% 53$ oranına sahip raporda ise konuya ilişkin açıklamada bulunulmamış veya raporda denetim alınmamıştır.

Tablo 3: Güvence Uygulayıcılar Tarafından Sera Gazı Güvence Denetimlerinde Tercih Edilen Standartların Frekans Dağılımı

\begin{tabular}{l|l|l|l|l|l}
\hline Güvence Uygulayıcılar & $\begin{array}{l}\text { Yalnız } \\
\text { ISAE 3000 }\end{array}$ & $\begin{array}{l}\text { Yalnız } \\
\text { ISAE3410 }\end{array}$ & $\begin{array}{l}\text { ISAE3000 ve } \\
\text { ISAE3410 }\end{array}$ & ISO 14064 & $\begin{array}{l}\text { Standart } \\
\text { Belirtilmemiş }\end{array}$ \\
\hline $\begin{array}{l}\text { 4 Büyük Bağımsız Denetim } \\
\text { Firması }\end{array}$ & 13 & 1 & 5 & 5 & - \\
\hline $\begin{array}{l}\text { Diğer Güvence Uygulayıcılar } \\
\text { Güvence Uygulayıcı } \\
\text { Belirtilmemiş }\end{array}$ & - & - & 1 & 18 & 1 \\
\hline Toplam & $\mathbf{1 3}$ & $\mathbf{1}$ & $\mathbf{6}$ & $\mathbf{2 4}$ & 11 \\
\hline
\end{tabular}

Güvence uygulayıc1ların sera gazı güvence raporları oluştururken tercih ettikleri standartların neler olduğunun belirlenmesine yönelik dördüncü araştırma sorusunun bulgularına Tablo 3'de yer verilmiştir. Denetim alınan 56 raporun 45'inde güvence için tercih edilen standartlara yer verilmiş, 11 'inde ise standartlara ve güvence uygulayıcılara ilişkin açıklamada bulunulmamıştır. Sera gazı beyanlarına ilişkin en fazla tercih edilen standart ISO 14064 standart serileri olmuştur. Bu standartları en fazla bağımsız denetçi dışında kalan diğer güvence uygulayıcıları kullanmıştır. Bağımsız denetçiler ise en fazla ISAE 3000 standardını tercih etmiştir. ISAE 3410 standardı, ISAE 3000 standardı ile kullanılmıştır. Araştırma kapsamında değerlendirilen 100 finansal olmayan raporun sadece 7'sinde ISAE 3410 standardı kullanılmıştır. Uluslararası düzeyde yeni kullanılmaya başlanan standardın ülkemizdeki bilinirliği ve tanınırlığının yapılan araştırma çerçevesinde düşük olduğunu söylemek mümkündür.

\section{SONUÇ ve DEĞERLENDİRME}

Duyarlı bir kurum olmak isteyen tüm işletmelerin şeffaflık ve hesap verebilirlik ilkelerini temel almaları, ekonomik faaliyetlerini gerçekleştirirken çevre ve sosyal ortam ile de uyum için de olmaları sürdürülebilir olmalarının temel koşullarındandır. Son yıllarda işletmelerin sürdürülebilirliklerini sağlamak adına finansal olmayan raporlar hazırladıkları ve bu raporlarda sundukları bilginin doğruluğu için güvence denetimi aldıkları görülmektedir. İşletmelerin güvence denetimi aldıkları 
konuların başında da sera gazları/karbon faaliyetleri gelmektedir. İşletmeler sera gazı emisyonlarına ilişkin sundukları bilgilerin doğruluğuna dair paydaşlarına denetim raporlarını sunmaktadırlar. $\mathrm{Bu}$ çalışmada da sunulan bu raporların kapsamının belirlendiği standart ISAE 3410 incelenmekte ve ülkemizde standarda ilişkin farkındalık düzeyi belirlenmek istenmektedir.

BIST Sürdürülebilirlik endeksindeki işletmelerde ISAE 3410 standardının kullanım düzeyini ölçmeyi amaçlayan çalışmanın sonuçları genel olarak değerlendirildiğinde şunları ifade etmek mümkündür; çalışmada BIST sürdürülebilirlik endeksinde yer alan işletmelerin finansal olmayan raporları ilk olarak Perego (2009), Manetti ve Becatti (2009), Kolk ve Perego (2010), Perego ve Kolk (2012), Mock vd. (2013) tarafından yapılan çalışmalara benzer şekilde, incelenen rapor sayısı, denetimli rapor sayısı açısından sektörel sınıflandırmaya tabi tutulmuştur. İmalat sanayi işletmelerin en fazla sera gazı beyanına ve sera gazı güvence denetimine sahip sektör olduğu görülmektedir. Finansal olmayan raporlarda sera gazı beyanlarına ilişkin açıklama oranı \%80 olmaktadır. Bu raporların \%44'ünde bağımsız güvence denetimi bulunmaktadır. Raporların \%42'sinde sera gazı beyanları için sınırlı güvence verilmektedir. Manetti ve Becatti (2009), Gürtürk ve Hann (2016) tarafından yapılan çalışmalarda da sınırlı güvenceye sahip güvence beyanların fazla sayıda olduğu görülmektedir. Raporlarda bağımsız denetçiler dışında kalan diğer güvence uygulayıcılar daha fazla tercih edilmiştir. Perego (2009), Fernandez-Feija, Romeo ve Ruiz (2016), Gürtürk ve Hann, 2016 tarafından yapılan çalışmalarda güvence uygulayıcısı olarak daha çok bağımsız denetçiler tercih edilirken, Mock vd. (2007) ve Mock vd. (2013) çalışmalarında ise dört büyük denetim firması dışındaki diğer güvence uygulayıcılarının daha çok tercih edildiği görülmektedir.

İşletmeler tarafından sera gazı salınımıyla ilgili üretilen bilgilerin ISEA 3410 ve ISO 14064 standartlarıyla denetlenmesi ve sonuçların raporlanması tüm paydaşları için güvence oluşturacak bir unsurdur. Sunulan bu güvence doğabilecek olumsuz durumların engellenmesine, yönetimsel karar almada etkinlik sağlanmasına, sürdürülebilirlik açısından sorumlulukların yerine getirilmesine, paydaş beklentilerinin karşılanmasına da katkıda bulunacaktır.

Güvence denetimleri ve sera gazı beyanlarına ilişkin güvence denetim standardı ISAE 3410 ülkemiz literatürü için oldukça yeni araştırma konularıdır. Bu çalışmanın amacı da güvence denetimini ve ISAE 3410 güvence standardını açıklamak, ülkemizde bu standardın farkındalığına ilişkin mevcut durumu görebilmek ve bu alanların tanınırlığına fayda sağlayabilmektir. Uluslararası literatür incelendiğinde 20 yıldan fazla bir zamandır işletmelerin finansal olmayan raporları için güvence hizmetleri aldıkları görülmektedir. Denetim hizmeti sunan kuruluşlardan alınan güvence hizmetleri için ISAE 3000, ISAE 3410 gibi birtakım standartlar geliştirilmiştir. Bu çalışmada da ülkemizde 2015 yılında GDS 3410 olarak çevirisi yapılan ISAE 3410 standardının farkındalık düzeyi belirlenmek istenmiştir. Endeksin ve standardın oldukça yeni olması bizim çalışmamız için önemli iki kısıttır. Endeksin kapsamı genişledikçe, güvence denetim hizmetleri işletmelerce bilinir ve tercih edilir oldukça konuya ilişkin istatistiksel ve ekonometrik yöntemler de kullanarak daha kapsamlı araştırmalar mümkün olacaktır.

Ulusal ve uluslararası düzeyde henüz yeni yeni uygulama alanı bulan bu standartların güvence uygulayıcıları tarafından bilinir olmasının da kullanılabilirliğini kolaylaştıracağı öngörülmektedir.

Bilgilendirme / Acknowledgement: Bu çalışma II. Business and Organization Recearch Congress 'de (İzmir) 05/09/2019 tarihinde sunulan özet bildirinin genişletilmiş halidir 


\section{KAYNAKÇA}

Altuğ., T. ve Özkan., F. Z. (2015). Sera gazı emisyonlarının izlenmesi, doğrulanması ve raporlanması. Verimlilik Dergisi, (2), 68-86.

Altıntaş, N., N. (2010). Bağımsız denetim ve vergi denetimi dışındaki güvence hizmetleri: Türkiye'deki uygulamalar hakkında bir araştırma. İstanbul Üniversitesi, Sosyal Bilimler Enstitüsü, yayımlanmamış doktora tezi, İstanbul.

Aras, G., Tezcan, N., ve Kutlu Furtuna, Ö. (2016). Geleneksel bankacilık ve katılım bankacillğında kurumsal sürdürülebilirlik performansının Topsis yöntemiyle karşılaştırılması. Istanbul Management Journal, 58-81.

Atabay., E. (2018). Destek hizmet kuruluşlarındaki kontrollere yönelik güvence hizmetleri (GDS:3402) Türkiye'de finansal sektördeki farkındalığın ölçümlenmesi. İstanbul: Türkiye Bankalar Birliği.

Çıtak, N. (2015). Hesap verebilirlik accountability aal000 güvence standartları serileri. İstanbul: Türkmen Yayınları.

Dinç., E. ve Atabay., E. (2016). Güvence denetim standartları ve güvence denetim süreci. Süleyman Demirel Üniversitesi İktisadi ve İdari Bilimler Fakültesi Dergisi, 21(5), 1527-1541.

Fernandez Feijoo., B, Romeo., S., ve Ruiz., S. (2016). The assurance market of sustainability reports: What do accounting firms do? Journal of Cleaner Production, 139, 1128-1137.

Gürtük., A. ve Hahn., R. (2016). An empirical assessment of assurance statements in sustainability reports: Smoke screens or enlightening information?. Journal of Cleaner Production, 136, 3041.

Kardeş-Selimoğlu., S. ve Özsözgün-Çalışkan., A. (2016a). Sürdürülebilirlik bağlamında uluslararası güvence denetimi standardı GDS (ISAE) 3410- Sera gazı beyanları I. Muhasebe ve Denetime Bakış Dergisi, 47, 1-20.

Kardeş-Selimoğlu., S. ve Özsözgün-Çalışkan., A. (2016b). Sürdürülebilirlik bağlamında uluslararası güvence denetimi standardı GDS (ISAE) 3410- Sera gazı beyanları II. Muhasebe ve Denetime Bakış Dergisi, 48, 1-20.

Kolk., A., ve Perego, P. (2010). Determinants of the adoption of sustainability assurance statements: An international investigation. Business Strategy and the Environment, 19, 182-198. DOI: 10.1002/bse.643.

Manetti, G., ve Becatti, L. (2009). Assurance services for sustainability reports: Standards and empirical evidence. Journal of Business Ethics, 87, 289-298. DOI 10.1007/s10551-008-9809-x.

Mock, T. J., Strohm, C., ve Swartz, K. M. (2007). An examination of worldwide assured sustainability reporting. Australian Accounting Review, 17(1), 67-77.

Mock, T. J., Rao, S. S. and Srivastava, R. P. (2013), The development of worldwide sustainability reporting. Assurance. Australian Accounting Review, 23, 280-294, DOI:10.1111/auar.12013.

O'Dwyer, B., ve Owen, D. L. (2005). Assurance statement practice in environmental, social and sustainability reporting: A critical evaluation. The British Accounting Review, 37(2), 205-229.

Perego., P. (2009). Causes and consequences of choosing different assurance providers: An international study of sustainability reporting. International Journal of Management, 26(3), 412-425.

Perego, P., ve Kolk, A., (2012). Multinationals' accountability on sustainability: The evolution of third-party assurance of sustainability reports. Journal Business Ethics,110 (2), 173-190. 
Sezer Özçelik., A.G. (2016). Türkiye Kalkınma Bankası kurumsal sera gazı envanteri ve raporu. 22 Haziran 2019 tarihinde http: //www.kalkinma.com.tr/data/file/çevreci kalkinma/2016 yili Sera Gazi Envanteri ve Raporu.pdf adresinden erişildi.

Simnett., R. Ve Nugent., M. (2007). Developing and assurance standard for carbon emissions disclosures. Australian Accounting Rewiev, 17(2), 37-47.

Yükçü, S., ve Kaplanoğlu, E. (2016). Sürdürülebilir kalkınmada finansal olmayan raporlamanın önemi. Muhasebe ve Bilim Dünyası Dergisi, 18(Özel Say1-1), 63-101. 